\title{
ANALISIS KEMAMPUAN PENALARAN SISWA DALAM PEMECAHAN MASALAH MATEMATIKA SISWA KELAS IV
}

\author{
Khodijah Habibatul Izzah ${ }^{1}$, Mira Azizah² \\ 1,2 PGSD Fakultas IImu Pendidikan Universitas PGRI Semarang \\ e-mail: khodijah.izzaah@gmail.com ${ }^{1}$, azizahm1@gmail.com²
}

\begin{abstract}
Abstrak
Penelitian ini bertujuan untuk mengetahui seberapa besar tingkat kemampuan penalaran siswa dalam pemecahan masalah matematika di kelas IV SDN Tambakrejo 01 Semarang. Penelitian ini adalah penelitian kualitatif deskriptif dengan pengumpulan data dilakukan melalui observasi, angket, wawancara dan dokumentasi serta untuk pengumpulan data kemampuan penalaran matematika siswa menggunakan soal tes. Keabsahan data dilakukan dengan cara triangulasi teknik. Pembelajaran matematika termasuk dalam kategori sangat baik dengan persentase sebesar $87,5 \%$, data klasifikasi penalaran matematika didapatkan persentase sebesar 22,5\% pada aspek memahami pengertian, $50 \%$ pada aspek berpikir logis, $15 \%$ pada aspek memahami contoh negatif, $17,5 \%$ untuk aspek berpikir deduksi, 17,5\% untuk aspek berpikir sistematis, 30\% pada aspek berpikir konsisten, $12,5 \%$ pada aspek menarik kesimpulan, $22,5 \%$ pada aspek menentukan strategi, dan hasil terendah sebesar $10 \%$ untuk aspek berpikir membuat alasan, serta persentase tertinggi $52,5 \%$ pada aspek penalaran menentukan metode. Secara keseluruhan didapatkan hasil persentase sebesar $25 \%$ dengan kategori rendah.
\end{abstract}

Kata Kunci : Kemampuan Penalaran, Pemecahan Masalah, Sekolah Dasar

\begin{abstract}
This research aims to determine how big the level of reasoning abilities of students in solving mathematical problems in class IV SDN Tambakrejo 01 Semarang. This research is descriptive qualitative research with data collection carried out through observation, questionnaires, interviews and documentation as well as for data collection of mathematical reasoning abilities of students using test questions. The validity of the data is done by means of triangulation techniques. Mathematics learning is included in the excellent category with a percentage of $87.5 \%$, mathematical reasoning classification data obtained a percentage of $22.5 \%$ in terms of understanding understanding, $50 \%$ in aspects of logical thinking, $15 \%$ in aspects of understanding negative examples, $17.5 \%$ for aspects of deduction thinking, $17.5 \%$ for aspects of systematic thinking, 30\% on aspects of consistent thinking, $12.5 \%$ on aspects of drawing conclusions, $22.5 \%$ on aspects of determining strategy, and lowest results by $10 \%$ for thought aspects making excuses, and the highest percentage of $52.5 \%$ in the aspect of reasoning determines the method. Overall, the percentage is $25 \%$ with a low category.
\end{abstract}

Keywords : Reasoning Ability, Problem Solving, Elementary School 


\section{Pendahuluan}

Matematika adalah ilmu yang berperan penting dalam berbagai aspek kehidupan dan tidak dapat terlepas dari kehidupan. Matematika juga memiliki peran penting dalam perkembangan ilmu pengetahuan dan teknologi, baik sebagai alat bantu dalam penerapanpenerapan bidang ilmu lain maupun dalam pengembangan matematika itu sendiri. Karena pentingnya matematika dalam kehidupan sehari-hari, matematika dijadikan salah satu pelajaran wajib pada setiap jenjang pendidikan di sekolah. Standar matematika di sekolah meliputi standar isi atau materi (mathematical content) dan standar proses (mathematical processes) (Shadiq dalam Hidayati dan Widodo 2015:131). Standar proses terdiri atas pemecahan masalah (problem solving), penalaran (reasoning), dan komunikasi (communication).

Peraturan Menteri No. 21 Tahun 2016 tentang Standar Isi menyebutkan bahwa proses pendidikan dimaksudkan untuk membentuk kompetensi dengan substansi tujuan pendidikan nasional dalam aspek sikap spiritual dan sikap sosial, pengetahuan, serta keterampilan. Masing-masing aspek memiliki proses pemerolehan yang berbeda. Pada aspek keterampilan khususnya, Keterampilan dapat diperoleh melalui aktivitas-aktivitas: mengamati, menanya, mencoba, menalar, menyaji, dan mencipta. Ditetapkannya proses menalar dalam kompetensi keterampilan, itu berarti bahwa penalaran menjadi salah satu aspek penting untuk dilibatkan dalam suatu pembelajaran yang tentunya harus dimiliki oleh siswa. Secara konseptual, kemampuan berpikir atau bernalar matematis telah tersurat dalam rangkaian kompetensi pembelajaran yang dituangkan dalam Permendikbud RI Nomor 37 Tahun 2018 tentang Kompetensi Inti dan Kompetensi Dasar Satuan Pendidikan Dasar dan Menengah. Khususnya pada pembelajaran matematika, dimensi berpikir atau bernalar matematis tertuang dalam rangkaian kompetensi pembelajaran yang tersusun menjadi satu kecakapan khusus yang harus dikuasai siswa terutama pada jenjang pendidikan dasar.

Menurut Winarti (2015) Kurikulum 2013 menjelaskan bahwa siswa diharapkan tidak hanya dapat penerapan konsep saja, tetapi lebih kepada bagaimana konsep itu dapat diterapkan dalam berbagai macam situasi, dan kemampuan siswa dalam bernalar dan berargumentasi tentang bagaimana soal itu dapat diselesaikan. Berdasarkan pemaparan sebelumnya, terlihat bahwa kemampuan penalaran merupakan salah satu dari kompetensi yang harus dimiliki oleh peserta didik. Hal itu karena penalaran merupakan salah satu standar yang sangat dibutuhkan dalam pembelajaran matematika dan menjadi salah satu tujuan dari pembelajaran matematika serta sangat dibutuhkan untuk pemecahan masalah dalam kehidupan sehari-hari. Depdiknas menyatakan bahwa materi matematika dan penalaran matematika merupakan dua hal yang tidak dapat dipisahkan, yaitu materi matematika dipahami melalui penalaran dan penalaran dipahami dan dilatih melalui belajar materi matematika. Menurut Ario (2016) mengingat pentingnya penalaran matematis maka perlu dilakukan analisa mendalam tentang kemampuan penalaran matematis siswa. Analisa ini berupa tingkat penguasaan kemampuan penalaran matematis siswa setelah mengikuti suatu pembelajaran serta ragam kesalahan siswa dalam menjawab soal-soal kemampuan penalaran matematis. Hasil analisa ini nantinya akan berguna untuk menyusun suatu strategi atau metode pembelajaran yang dapat memperbaiki kesalahan-kesalahan yang terjadi pada siswa. Sehingga diharapkan kemampuan penalaran matematis siswa dapat ditingkatkan lagi di waktu mendatang.

Pembelajaran adalah proses interaksi siswa dengan guru, siswa dengan sumber belajar pada suatu lingkungan belajar. Pembelajaran merupakan bantuan yang diberikan guru agar dapat terjadi proses pemerolehan ilmu dan pengetahuan, penguasaan kemahiran dan kebiasaan, serta pembentukan sikap dan kepercayaan pada siswa. Dengan kata lain, pembelajaran adalah proses untuk membantu siswa agar dapat belajar dengan baik. Proses pembelajaran dialami sepanjang hayat seorang manusia serta dapat berlaku di manapun dan kapanpun. Pada proses pembelajaran, seharusnya siswa mendapatkan pengalaman belajar. Pengalaman belajar adalah semua proses, peristiwa dan aktivitas yang dialami anak didik untuk mendapatkan pengetahuan, keterampilan dan sikap. Setelah melalui proses pembelajaran diharapkan siswa memperoleh pengetahuan. Pengetahuan tidak dapat pindah 
begitu saja dari guru ke siswa melainkan siswa sendirilah yang mengkonstruksikan pengetahuan dari pengalaman kognitif mereka pada saat berinteraksi dengan lingkungan pada proses pembelajaran. Untuk mengoptimalkan proses pembelajaran pemerintah telah memberikan suatu standar proses dalam pelaksanaan pembelajaran. Standar proses pembelajaran tersebut tertuang dalam Peraturan Menteri Pendidikan Nasional No. 41 tahun 2007 tanggal 23 November 2007. Standar proses tersebut meliputi perencanaan, pelaksanaan, penilaian dan pengawasan proses pembelajaran yang efektif dan efisien. Pembelajaran yang bermakna merupakan suatu proses dikaitkannya informasi baru pada konsep-konsep relevan yang terdapat dalam struktur kognitif seseorang. Siswa mengkonstruksi pengetahuan mereka melalui interaksi mereka dengan objek, fenomena, pengalaman dan lingkungan mereka. Suatu pengetahuan akan diterima jika pengetahuan itu dianggap relevan dan konsisten untuk menyelesaikan masalah atau fenomena yang sesuai. Ini merupakan proses penyesuaian konsep-konsep dan ideide baru dengan kerangka berpikir, yang telah ada dalam pikiran mereka. Apabila siswa benar-benar memahami suatu konsep dalam pembelajaran, siswa akan dapat menerapkan konsep tersebut pada situasi baru dan hasil belajar siswa akan semakin baik. Berdasarkan beberapa pengertian di atas dapat disimpulkan bahwa pembelajaran adalah upaya untuk mengorganisasikan lingkungan untuk menciptakan kondisi belajar bagi peserta didik, yang kegiatannya dirancang melibatkan proses mental dan fisik melalui interaksi antar peserta didik, peserta didik dengan guru, lingkungan, dan sumber belajar lainnya dalam rangka pencapaian kompetensi dasar.

Pembelajaran matematika bagi para siswa merupakan pembentukan pola pikir dalam pemahaman suatu pengertian maupun dalam penalaran suatu hubungan diantara pengertian-pengertian itu. Dalam pembelajaran matematika, para siswa dibiasakan untuk memperoleh pemahaman melalui pengalaman tentang sifat-sifat yang dimiliki dan yang tidak dimiliki dari sekumpulan objek (abstraksi). Siswa diberi pengalaman menggunakan matematika sebagai alat untuk memahami atau menyampaikan informasi misalnya melalui persamaanpersamaan, atau tabel-tabel dalam model-model matematika yang merupakan penyederhanaan dari soal-soal cerita atau soal-soal uraian matematika lainnya. Berdasarkan uraian diatas dapat disimpulkan, pembelajaran matematika adalah upaya untuk mengorganisasikan lingkungan untuk menciptakan kondisi belajar bagi peserta didik, yang kegiatannya dirancang melibatkan proses mental dan fisik melalui interaksi antar peserta didik, peserta didik dengan guru, lingkungan, dan sumber belajar lainnya dalam menelaah bentuk, struktur, susunan, besaran, dan konsep-konsep yang abstrak serta hubungannya, dalam rangka pencapaian kompetensi dasar.

Pusat Kurikulum Badan Penelitian dan Pengembangan Departemen Pendidikan Nasional mendeskripsikan sifat matematika dan bentuk pembelajaran yang mungkin dilaksanakan guru, sebagai berikut :

Tabel 1. Deskripsi Sifat Matematika dan Bentuk Pembelajaran

\section{Sifat Matematika}

Menggunakan cara berpikir dan bernalar berdasar pada pola dan hubungan

Aktivitas kreatif $\quad$ yang
melibatkan imajinasi, intuisi
dan penemuan

\section{Bentuk Pembelajaran}

1) Memberi kesempatan menemukan dan menyelidiki pola dan mendeskripsikan serta mencatat hasil temuannya.

2) Mendorong eksplorasi dan eksperimen (atau mencoba dengan berbagai cara).

3) Mendorong untuk menunjukkan konsistensi dan inkonsistensi, kesamaan dan perbedaan.

4) Membantu membuat generalisasi dari temuan.

Mendorong siswa mengembangkan pemikiran divergen, orisinil dan inisiatif, rasa ingin tahu, membuat prediksi dan dugaan, mencoba-coba. 
$\begin{array}{ll}\text { Sebagai cara memecahkan 1) } & \text { Memberikan problem yang menarik, mendorong } \\ \text { problem } & \text { untuk memecahkan problem mereka sendiri, } \\ & \text { membantu mengidentifikasi informasi yang } \\ & \text { diperlukan untuk memecahkan problem. } \\ \text { 2) } & \text { Mendorong berpikir logis, konsisten, bekerja } \\ & \text { sistematis, dan mencatat prosedur atau cara } \\ & \text { menjawab soalnya. } \\ \text { 3) } & \text { Mengembangkan dan menggunakan pengetahuan } \\ & \text { dan keterampilan matematika untuk memecahkan } \\ & \text { problem, membantu mereka mengetahui bagaimana } \\ & \text { dan kapan konsep matematika tertentu dipakai. }\end{array}$

Sebagai alat komunikasi Memberi kesempatan untuk menjelaskan, memberi informasi atau ide contoh, memberi argumen. Mendorong siswa membaca atau menulis aspek matematika melalui gambar, simbol diagram, tabel, peta, kata-kata.

Kemampuan penalaran dalam matematika adalah suatu kemampuan menggunakan aturan-aturan, sifat-sifat atau logika matematika untuk mendapatkan suatu kesimpulan yang benar. Penalaran tidak terlepas dari realitas, sebab yang dipikirkan adalah realitas, yaitu hokum realitas yang sejalan dengan aturan berpikir dan dengan dasar realitas yang jelas serta menggunakan hukumhukum berpikir. Menurut Agustin (2016) penalaran adalah suatu kegiatan berpikir logis untuk mengumpulkan fakta, mengelola, menganalisis, menjelaskan, dan membuat kesimpulan. Menurut Russeffendi, matematika lebih menekankan kegiatan dalam dunia rasio (penalaran), bukan menekankan dari hasil eksperimen atau hasil observasi. Matematika terbentuk karena pikiran-pikiran manusia yang berhubungan dengan idea, proses, dan penalaran. Pada tahap awal matematika terbentuk dari pengalaman manusia dalam dunianya secara empiris. Kemudian pengalaman itu diproses dalam dunia rasio, diolah secara analisis dengan penalaran di dalam struktur kognitif sehingga sampai terbentuk konsep-konsep matematika. Shadiq (dalam Hidayati dan Widodo, 2015:132) menyatakan definisi penalaran menurut Copi yaitu penalaran merupakan kegiatan, proses atau aktivitas berpikir untuk menarik suatu kesimpulan atau membuat suatu pernyataan baru berdasarkan pada beberapa pernyataan yang diketahui benar ataupun yang dianggap benar yang disebut premis. Menurut Suriasumantri (2010:42) penalaran merupakan suatu proses berpikir dalam menarik sesuatu kesimpulan yang berupa pengetahuan. Berdasarkan uraian dapat disimpulkan bahwa penalaran adalah suatu proses atau aktivitas berpikir untuk menarik kesimpulan atau membuat suatu pernyataan baru yang benar berdasarkan pada beberapa pernyataan yang diketahui sebelumnya menggunakan cara logis. Penalaran merupakan salah satu tujuan dari mata pelajaran matematika. Untuk meningkatkan kemampuan tersebut, tentunya tidak terlepas dari upaya pembelajaran di sekolah. Walaupun pembelajaran di sekolah selama ini memiliki peran tinggi pada keaktifan siswa, misalnya melalui pembentukan kelompok belajar, namun ternyata dampaknya terhadap kemampuan penalaran siswa belum terlihat. Untuk meningkatkan kemampuan penalaran yaitu dengan perbaikan proses pembelajaran melalui penerapan strategi metakognitif. Strategi metakognitif dapat mendorong siswa untuk belajar mencari alasan terhadap solusi yang benar dan lebih mendorong siswa untuk membangun, mengkonstruksi, dan mempertahankan solusi-solusi yang argumentatif dan benar. Memberikan alasan atau bukti terhadap kebenaran solusi merupakan salah satu indikator kemampuan penalaran. Kemampuan mengajukan dugaan merupakan salah satu indikator dari kemampuan penalaran. Kemampuan penalaran juga sangat diperlukan dalam memahami suatu konsep materi pokok. Tanpa adanya kemampuan penalaran, maka peserta didik akan mengalami kesulitan dalam menyelesaikan suatu permasalahan. 
a. Jenis-jenis Penalaran

Dalam proses pembelajaran tertumpu pada dua macam penalaran, yaitu penalaran induktif dan penalaran deduktif.

1) Penalaran induktif Penalaran induktif yaitu suatu aktivitas berpikir untuk menarik suatu kesimpulan atau membuat suatu pernyataan baru yang bersifat umum berdasarkan pada pernyataan khusus yang diketahui benar. Pembelajaran diawali dengan memberikan contoh-contoh atau kasus khusus menuju konsep atau generalisasi.

2) Penalaran deduktif Penalaran deduktif yaitu kebenaran suatu konsep atau pernyataan diperoleh sebagai akibat logis dari kebenaran sebelumnya. Proses pembuktian secara deduktif akan melibatkan teori atau rumus matematika lainnya yang sebelumnya sudah dibuktikan kebenarannya secara deduktif juga. Peserta didik sering mengalami kesulitan memahami makna matematika dalam pembelajaran dengan pendekatan deduktif. Hal ini disebabkan peserta didik baru memahami konsep atau generalisasi setelah disajikan berbagai contoh.

b. Indikator Penalaran Matematika

Penalaran Matematika yang mencakup kemampuan untuk berpikir secara logis dan sistematis merupakan ranah kognitif matematik yang paling tinggi.

Penalaran matematika (mathematical reasoning) diperlukan untuk menentukan apakah sebuah argumen matematika benar atau salah dan juga dipakai untuk membangun suatu argumen matematika. Penalaran matematika tidak hanya penting untuk melakukan pembuktian (proof) atau pemeriksaan program (program verification), tetapi juga untuk melakukan inferensi dalam suatu sistem kecerdasan buatan (artificial intelligence). Keterampilan penalaran meliputi memahami pengertian, berpikir logis, memahami contoh negatif, berpikir dedukatif, berpikir sistematis, berpikir konsisten, menarik kesimpulan, menentukan metode, membuat alasan, dan menentukan strategi..

Mengajarkan matematika tidaklah mudah karena fakta menunjukkan bahwa para siswa mengalami kesulitan dalam mempelajari matematika. Tidak sedikit guru matematika yang kesulitan dalam mengajarkan kepada siswanya bagaimana menyelesaikan problem matematika. Kesulitan itu lebih disebabkan suatu pandangan yang mengatakan bahwa jawaban akhir dari permasalahan merupakan tujuan utama dari pembelajaran. Prosedur siswa dalam menyelesaikan permasalahan kurang, bahkan tidak diperhatikan oleh guru karena terlalu berorientasi pada kebenaran jawaban akhir. Padahal dalam pembelajaran pemecahan masalah proses penyelesaian suatu problem yang dikemukakan siswa merupakan tujuan utama dalam pembelajaran matematika (Suherman dalam Sulianto 2011: 20).

Berdasarkan hasil observasi dan wawancara dengan guru kelas IV SD Negeri Tambakrejo 01 Semarang, kemampuan penalaran siswa dalam memecahkan masalah matematika masih rendah. Hal tersebut ditunjukkan oleh proses pembelajaran yang masih didominasi dengan metode ceramah, kurangnya motivasi siswa dalam belajar matematika, hasil belajar siswa yang masih rendah dan masih rendahnya kemampuan siswa dalam menyelesaikan soal pemecahan masalah matematika. Mengajar menggunakan metode ceramah saja dapat mempersulit siswa memahami konsep memecahkan masalah dalam pelajaran matematika, jadi siswa tidak bisa menerima pelajaran yang telah diberikan gurunya sehingga kemampuan siswa dalam memecahkan masalah matematika kurang dari apa yang diharapkan.

Sekolah Dasar (SD) pada hakikatnya merupakan satuan atau unit lembaga sosial (Social Institusional) yang diberi amanah atau tugas khusus (specific tasks) oleh masyarakat untuk menyelenggarakan pendidikan dasar secara sistematis. Dengan demikian, sebutan sekolah dasar merujuk pada satuan lembaga sosial yang diberi amanah spesifik oleh masyarakat untuk menyelenggarakan pendidikan dasar penggalan pertama selama enam tahun untuk dilanjutkan pada penggalan pendidikan lebih lanjut (Anwar, 2012). Menurut Novianti (2016) salah satu pelajaran yang terdapat di tingkat sekolah dasar adalah matematika. Matematika merupakan salah satu komponen dari serangkaian mata pelajaran yang mempunyai peranan penting dalam pendidikan. Matematika merupakan salah satu bidang studi yang mendukung perkembangan ilmu pengetahuan dan teknologi. 
Apalagi matematika sangat berperan penting dalam kehidupan sehari-hari. Untuk itu matematika sangat penting di ajarkan sejak Sekolah Dasar untuk melatih kemampuan berfikir siswa. Namun kenyataannya sampai saat ini masih banyak siswa merasa matematika sebagai mata pelajaran yang sulit, tidak menyenangkan, bahkan hal yang menakutkan. Hal ini dikarenakan masih banyak siswa yang mengalami kesulitan-kesulitan dalam mengerjakan soal-soal matematika. Kesulitankesulitan yang dihadapi siswa dikarena pada saat pembelajaran objek yang digunakan masih bersifat abstrak. Sehingga siswa sulit untuk memahami konsep pembelajaran matematika. Pembelajaran matematika di sekolah dasar tidak hanya diarahkan pada peningkatan kemampuan siswa dalam berhitung, tetapi juga diarahkan kepada peningkatan kemampuan siswa dalam pemecahan masalah (Problem Solving), baik masalah matematika maupun masalah lain yang secara kontekstual menggunakan matematika untuk memecahkannya. Mata pelajaran matematika diantaranya bertujuan agar peserta didik memiliki kemampuan pemahaman konsep, penalaran, memecahkan masalah, mengkomunikasikan gagasan, dan memiliki sikap menghargai kegunaan matematika dalam kehidupan (BSNP, 2006).

Dari tujuan pembelajaran matematika di sekolah dasar tersebut, nampak bahwa pemecahan masalah menjadi fokus penting dalam pembelajaran matamatika sehingga secara jelas terdapat pada kurikulum mata pelajaran matematika mulai jenjang sekolah dasar sampai sekolah menengah. Mengenai masalah matematika, Menurut Gelar (2016) Matematika diakui sebagai salah satu mata pelajaran yang dianggap sulit dan juga menakutkan. Hal ini menjadi pekerjaan rumah bagi guru matematika untuk mengubah pendapat kebanyakan orang tentang matematika. Pada tingkat dasar pun sebagian besar siswa kurang menyukai matematika karena matematika banyak rumus yang harus dihafal jadi sulit untuk dipahami. Tahap penyelesaian masalah yang akan digunakan dalam penelitian ini adalah tahap pemecahan masalah menurut $G$ Polya. Pemilihan tahap pemecahan masalah menurut $G$ Polya karena tahap-tahap pemecahan masalah yang dikemukakan oleh G Polya sederhana, aktifitas pada setiap tahapnya jelas, dan memungkinkan siswa memperoleh pengalaman menggunakan pengetahuan serta keterampilan yang telah dimiliki untuk memecahkan masalah. Dalam setiap standar kompetensi, ada salah satu kompetensi dasar yang mengarahkan siswa untuk mampu menggunakan konsep-konsep matematika dalam menyelesaikan masalah. Pelaksanaan pembelajaran masalah di sekolah dasar tidaklah semudah yang perkirakan. Ada banyak faktor yang menghambat terlaksananya pembelajaran pemecahan masalah secara optimal, tidak hanya faktor guru saja, tetapi faktor tuntunan kurikulum yang membuat guru terdesak dengan waktu terbatas sehingga tidak fokus terhadap kemampuan pemecahan masalah.

\section{Metode}

Metode yang digunakan pada penelitian ini adalah metode kualitatif. Lokasi penelitian di SD Negeri Tambakrejo 01 Semarang. Pengumpulan data dilakukan melalui observasi, angket, wawancara dan dokumentasi serta untuk pengumpulan data kemampuan penalaran matematis siswa menggunakan soal tes. Keabsahan data dilakukan dengan cara triangulasi teknik.

\section{Hasil dan Pembahasan}

Data hasil penelitian aspek penalaran siswa diperoleh dari uji tes yang dilakukan pada kelas IV ditampilkan pada tabel 3 berikut: 
Tabel 2. Data Hasil Penelitian Aspek Penalaran Siswa

\begin{tabular}{clll}
\hline No. Soal & Aspek Penalaran & Persentase Jawaban Benar & Skor Rata- Rata \\
\hline 1 & Memahami pengertian & $22,5 \%$ & 6,77 \\
2 & Berpikir logis & $50 \%$ & 8,57 \\
3 & Memahami contoh negatif & $15 \%$ & 6,92 \\
4 & Berpikir deduksi & $17,5 \%$ & 7,8 \\
5 & Berpikir sistematis & $17,5 \%$ & 7,77 \\
6 & Berpikir konsisten & $30 \%$ & 8,27 \\
7 & Menarik kesimpulan & $12,5 \%$ & 5,92 \\
8 & Menentukan metode & $52,5 \%$ & 8,8 \\
9 & Membuat alasan & $10 \%$ & 6 \\
10 & Menentukan strategi & $22,5 \%$ & 6,75 \\
\hline
\end{tabular}

Berdasarkan analisis data yang telah dilakukan, pembelajaran matematika termasuk dalam kategori sangat baik dengan persentase sebesar $87,5 \%$, data klasifikasi penalaran matematika didapatkan persentase sebesar $22,5 \%$ pada aspek memahami pengertian, $50 \%$ pada aspek berpikir logis, 15\% pada aspek memahami contoh negatif, 17,5\% untuk aspek berpikir deduksi, 17,5\% untuk aspek berpikir sistematis, 30\% pada aspek berpikir konsisten, $12,5 \%$ pada aspek menarik kesimpulan, 22,5\% pada aspek menentukan strategi, dan hasil terendah sebesar $10 \%$ untuk aspek berpikir membuat alasan, serta persentase tertinggi 52,5 $\%$ pada aspek penalaran menentukan metode. Secara keseluruhan didapatkan hasil persentase sebesar $25 \%$ dengan kategori rendah.

Dilihat dari hasil persentase pada tabel 3 dari masing- masing soal mengalami fluktuasi, terlihat adanya naik turun persentase pada masing-masing nomor dengan total keseluruhan soal sebanyak 10 soal. Pada beberapa soal didapatkan nilai persentase yang sama, terlihat pada soal nomor empat pada aspek penalaran menentukan berpikir dan soal nomor lima pada aspek berpikir sistematis dengan materi bangun datar dan segi banyak memiliki nilai persentase sebesar $17,5 \% \%$. Selanjutnya pada soal lainnya juga ditemukan hasil persentase yang sama yaitu dengan nilai persentase sebesar 22,5\% pada soal nomor satu dan sepuluh yang juga ditemukan pada materi bangun datar dan segi banyak. Selain itu tidak ada lagi nilai persentase yang sama. Secara keseluruhan didapatkan nilai persentase terendah yaitu sebesar $10 \%$ dan nilai persentase tertinggi sebesar $52,5 \%$.

Perbedaan hasil persentase pada masing-masing soal bisa diakibatkan oleh beberapa faktor, satu diantaranya adalah karena tingkatan soal disetiap aspek penalaran yang berbeda. Faktor lain yang dapat menyebabkan rendahnya nilai persentase adalah karena kurangnya pemahaman siswa untuk memahami isi dari soal penalaran itu sendiri. Sehingga siswa merasa kesulitan untuk mengerjakan, mencari cara, serta memecahkan masalah dari perosoalan yang ada. Sedangkan adanya perolehan hasil persentase dengan nilai yang besar, itu berarti siswa mampu memahami bentuk dan maksud soal serta bagaimana pemecahan masalah yang harus dilakukan pada soal dengan aspek penalaran yang ada.

Hasil uji coba menunjukkan minim dan rendahnya hasil persentase, tepatnya yang masih dibawah 50 \% dapat diartikan bahwa kecakapan bernalar siswa masih terbilang rendah dan belum bisa maksimal. Dilihat dari tabel hasil persentase setiap aspek penalaran menunjukkan bahwa persentase di bawah 50 \% lebih banyak dan mendominasi.

\section{Simpulan dan Saran}

Berdasarkan hasil penelitian dan hasil pembahasan yang telah diuraikan, maka bisa disimpulkan bahwa:

1. Hasil analisis terkait implementasi pembelajaran matematika di SD Negeri Tambakrejo 01 Semarang sudah terlaksana dengan sangat baik. Pada pelaksanaannya antara guru dan siswa tercipta interaksi yang baik dan dibeberapa kegiatan pembelajaran guru menggunakan media pada prosesnya. Pada proses pengamatan guru mampu 
menyampaiakan materi dengan bahasa lisan yang mudah dipahami oleh siswa. Hasil temuan dari kuesioner sebesar $90 \%$ menunjukkan kategori sangat baik.

2. Kemampuan penalaran matematika siswa kelas IV SD Negeri Tambakrejo 01 Semarang ditinjau dari aspek penalaran serta pemecahan masalah dengan materi segi banyak dan bangun datar pada beberapa aspek penalaran sudah menunjukkan hasil yang baik dan masuk pada kategori tinggi, namun masih didominasi oleh hasil dengan kategori rendah, dan beberapa masih menunjukkan hasil yang sangat rendah. Secara keseluruhan hasil persentase yang didapat adalah sebesar $25 \%$. Artinya kemampuan penalaran matematika siswa kelas IV SD Negeri Tambakrejo 01 Semarang masih rendah.

\section{Daftar Pustaka}

Agustin, Ririn Dwi. 2016. Kemampuan Penalaran Matematika Mahasiswa melalui Pendekatan Problem Solving. Jurnal Pedagogia ISSN 2089-3833 Vol. 5 No. 2 Hal. 179-183. https://www.researchgate.net/publication/. Diakses 23 Mei 2019.

Amir, Almira. 2014. Kemampuan Penalaran Dan Komunikasi Dalam Pembelajaran Matematika. Jurbal LOGARITMA (Vol: II, No: 1).

Anwar, Zul. 2012. Pelaksanaan Pembelajaran Matematika di Sekolah Dasar. Jurnal Penelitian IImu Pendidikan (JPIP) Vol. 5 No. 2 Hal. 24-32. https://journal.uny.ac.id/index.php/jpip/issue/view/672. Diakses 23 Mei 2019.

Ario, Marfi. 2016. Analisis Kemampuan Penalaran Matematis Siswa SMK setelah Mengikuti Pembelajaran Berbasis Masalah. Jurnal IImiah Edu Research Vol. 5 No. 2 Hal. 125134. https://media.neliti.com/media/publications/. Diakses 23 Mei 2019.

Depdiknas. 2002. Kurikulum Berbasis Kompetensi. Jakarta: Pusat Kurikulum Balitbang Depdiknas.

Depdiknas.2003. Kamus Besar Bahasa Indonesia. Jakarta: Balai Pustaka

Depdiknas. 2006. Kurikulum Tingkat Satuan Pendidikan. Jakarta: Depdiknas.

Gelar Dwirahayu, dan Nursida. 2016. Mengembangkan Pembelajaran Matematika Dengan Menggunakan Metode Permainan Untuk Siswa Kelas $1 \mathrm{Ml}$. Jurnal Matematika dan $\begin{array}{lllll}\text { Pendidikan Matematika } & \text { Vol. } 5 & \text { No.2 } & \text { Hal. 117-138. }\end{array}$ http://ejournal.unkhair.ac.id/index.php/. Diakses 23 Mei 2019.

Hidayati, Anisatul, dkk. 2015. Proses Penalaran Matematis Siswa Dalam Memecahkan Masalah Matematika Pada Materi Pokok Dimensi Tiga Berdasarkan Kemampuan Siswa Di Sma Negeri 5 Kediri. Jurnal Math Educator Nusantara (Vol:1 No:2).

Novianti, Fenti. 2018. Pengembangan Media Pembelajaran Matematika "Sate Bilangan" Materi Operasi Penjumlahan dan Pengurangan Bilangan Cacah Kelas I Sekolah Dasar. FKIP Universitas Jambi. http://repository.unja.ac.id/. Diakses 23 Mei 2019.

Sugiyono. 2010. Model Penelitian Pendidikan Pendekatan Kuantitatif, Kualitatif, dan $R \& D$. Bandung: Alfabeta.

Suherman, Erman. 2003. Strategi Pembelajaran Matematika Kontemporer. Bandung: JICA.

Sulianto, Joko, dkk. 2013. Implementasi Pembelajaran RME (Realistic Mathematic Education) Terhadap Penalaran Dan Kemampuan Memecahkan Masalah Matematika Siswa Kelas V SDN Karangayu 02 Semarang. Jurnal MALIH PEDDAS (Vol: 3 No: 2). 
Sulianto, Joko, dkk. 2018. Penerapan Metode Problem Solving Model Polya Terhadap Kemampuan Memecahkan Masalah Pada Materi Operasi Hitung Campuran Kelas 3 $S D$. Jurnal Sekolah (Vol:2 No: 2).

Sulianto, Joko. 2011. Keefektifan Model Pembelajaran Kontekstual dengan pendekatan Open Ended dalam aspek penalaran dan pemecahan masalah pada materi segitiga di kelas VII. Jurnal MALIH PEDDAS (Vol: 1 No. 1)

Winarti, Sri. 2015. Analisis Kemampuan Penalaran Siswa dalam Menyelesaikan Soal Serupa Pisa pada Siswa Kelas VIII. Fakultas Kegururan dan IImu Pendidikan Universitas Muhammadiyah Surakarta. http://eprints.ums.ac.id/. Diakses 23 Mei 2019. 